\title{
Factors affecting successful mobilization with plerixafor: an Italian prospective survey in 215 patients with multiple myeloma and lymphoma
}

\author{
Francesco Lanza, Roberto M. Lemoli, Attilio Olivieri, Daniele Laszlo, Massimo Martino, \\ Giorgina Specchia, Vincenzo Pavone, Manuela Imola, Annalisa Pasini, Giuseppe Milone, \\ Ilaria Scortechini, Elisabetta Todisco, Elena Guggiari, Nicola Cascavilla, Giovanni Martinelli, \\ Alessandro Rambaldi, and Alberto Bosi*
}

BACKGROUND: Although the efficacy of plerixafor in peripheral blood stem cell (PBSC) mobilization has been explored in several studies, factors associated with successful plerixafor mobilization after administration of granulocyte-colony-stimulating factor (G-CSF), with or without chemotherapy, have not been investigated. We analyzed data on PBSC mobilization from a large Italian database of lymphoma and myeloma plerixafor-treated patients.

STUDY DESIGN AND METHODS: Two endpoints were established to define successful mobilization: patients with at least $2 \times 10^{6} \mathrm{CD} 34+$ cells $/ \mathrm{kg}$ collected by three leukapheresis procedures and patients achieving a peak count of at least $20 \times 10^{6} \mathrm{CD} 34+$ cells/L during mobilization.

RESULTS: Plerixafor achieved successful mobilization in both predicted $(n=64)$ and proven poor mobilizers (PMs; $n=143$ ), classified according to the Gruppo Italiano Trapianto di Midollo Osseo (GITMO) criteria. Successful mobilization was independent of type of mobilization (steady state or chemotherapy); age; sex; disease; number or type of chemotherapy regimens preceding plerixafor; radiation therapy; prior treatment with melphalan, carmustine, lenalidomide, and radioimmune conjugates; and laboratory variables. Multivariate analysis identified previous fludarabine treatment and premobilization platelet count as predictors of successful mobilization.

CONCLUSION: This large, prospective, nationwide study confirmed plerixafor efficacy for mobilizing PBSCs when added to G-CSF with or without chemotherapy. Plerixafor can overcome negative effects of most predictors of poor mobilization to achieve satisfactory harvest both in predicted and proven PM.
$\mathrm{H}$

igh-dose chemotherapy followed by autologous stem cell transplantation (ASCT) is a standard therapeutic approach for patients with non-Hodgkin's lymphoma (NHL),

ABBREVIATIONS: ASCT $=$ autologous stem cell transplantation; GITMO = Gruppo Italiano Trapianto di Midollo Osseo; HL = Hodgkin's lymphoma; MM = multiple myeloma; NHL = non-Hodgkin's lymphoma; $\mathrm{PB}=$ peripheral blood; $\mathrm{PBSC}=$ peripheral blood stem cell; $\mathrm{PM}(\mathrm{s})=$ poor $\operatorname{mobilizer}(\mathrm{s})$; $\mathrm{ROC}=$ receiver operating characteristic.

From the Section of Hematology and BMT Unit, Cremona Hospital, Cremona, Italy; the Department of Hematology and Oncological Sciences, Institute of Hematology "L. \& A.

Seràgnoli," University of Bologna, Bologna, Italy; the Section of Hematology, University Hospital of Ancona, "Ospedali Riuniti," Ancona, Italy; the Hemato-Oncology Unit, Istituto Europeo Oncologico, Milan, Italy; the Section of Hematology, Reggio Calabria Hospital, Reggio Calabria, Italy; the Section of Hematology, University Hospital of Bari, Bari, Italy; the Section of Hematology, Tricase Hospital, Tricase, Italy; Section the of Hematology, Rimini Hospital, Rimini, Italy; the Section of Hematology, University Hospital Ferrarotto, Policlinico Vittorio Emanuele, Catania, Italy; the Section of Hematology, Humanitas Hospital, and the BMT Unit, S. Raffaele Hospital, Milan, Italy; the Section of Hematology, Hospital Casa Sollievo Sofferenza, S. Giovanni Rotondo, Italy; the Section of Hematology, Bergamo Hospital, Bergamo, Italy; and the Section of Hematology and BMT Unit, University Hospital “Careggi,” Florence, Italy.

Address correspondence to: Francesco Lanza, Section of Hematology and BMT Unit, Hospital of Cremona, Via Concordia, 1, 26100 Cremona, Italy; e-mail: f.lanza@ospedale.cremona.it.

*See Appendix S1, available as supporting information in the online version of this paper.

Received for publication January 16, 2013; revision received February 26, 2013, and accepted March 4, 2013.

doi: $10.1111 /$ trf. 12265

TRANSFUSION $* * ; * * * * * * *$. 
Hodgkin's lymphoma (HL), or multiple myeloma (MM). ${ }^{1}$ The preferred source of hematopoietic stem cells for ASCT is represented by peripheral blood stem cells (PBSCs), since they are easier to collect and engraft faster than marrow-derived cells. ${ }^{2,3}$

Historically, granulocyte-colony-stimulating factor (G-CSF) or granulocyte macrophage-CSF, with or without chemotherapy, have been used to mobilize stem cells. However, these strategies do not always result in successful mobilization..$^{3-6}$ A recent survey involving 1040 patients with NHL, HL, or MM, shows that a relevant proportion of patients $(6 \%-27 \%)$ failed to mobilize a sufficient number of CD34+ progenitor cells for ASCT regardless of whether G-CSF was used alone or with chemotherapy. ${ }^{5}$ Noteworthy, factors predicting successful PBSC mobilization in patients with hematologic malignancies are still poorly investigated, ${ }^{7-10}$ although their identification would improve collection efficiency and prevent unnecessary apheresis procedures, thus allowing a patient-tailored mobilization and collection strategy. ${ }^{11}$

Plerixafor (Mozobil, Genzyme BV, Naarden, Netherlands, Sanofi licencing distribution in Italy) is a novel CXCR4 chemokine receptor antagonist used in PBSC mobilization. ${ }^{12}$ The interaction of the CXCR4 receptor with the chemokine (C-X-C motif) ligand 12 (CXCL12) plays a pivotal role in retaining $\mathrm{CD} 34+$ cells in the marrow niches. ${ }^{12}$ Therefore, the blockade of this interaction leads to the mobilization of stem cells into peripheral blood (PB). ${ }^{12}$ The efficacy of plerixafor in the mobilization of PBSCs is supported by the results of two randomized, double-blind, multicenter trials in adult patients with NHL or MM. ${ }^{13,14}$ Moreover, the results of compassionateuse studies conducted in patients with lymphoma or MM demonstrated that plerixafor plus G-CSF successfully and safely induces stem cell mobilization in the majority of patients who had previously failed a mobilization attempt (i.e., collected CD34+ cells did not reach the minimum number to proceed to ASCT or patients did not undergo apheresis because of low PB CD34+ cell count) or patients who were predicted to be poor mobilizers (PMs; e.g., heavily treated patients). ${ }^{15-20}$ Although the efficacy of plerixafor in PBSC mobilization has been explored in several studies, to our knowledge the factors potentially associated with successful mobilization after the administration of this agent have not been specifically investigated. To this end, this study analyzes a large Italian database of patients treated with plerixafor.

\section{PATIENTS AND METHODS}

\section{Study setting and design}

This multicenter, prospective, observational cohort study was conducted in 23 Italian centers with experience in the treatment of hematologic malignancies and performance of stem cell mobilization and ASCT between January 2010 and December 2011. The study was conducted in accordance with the Declaration of Helsinki, and the ethical committee of each center approved the study protocol. All patients signed an informed and educated consent before their inclusion in the study.

\section{Patients and interventions}

Patients with NHL, HL, or MM requiring PBSC mobilization were screened for inclusion in this study. Mobilization was performed using G-CSF, with or without chemotherapy, depending on individual center policy. $\mathrm{G}$-CSF was given at a dosage of $10 \mu \mathrm{g} / \mathrm{kg}$ when used alone and $5 \mu \mathrm{g} / \mathrm{kg}$ when administered after chemotherapy. Plerixafor was given at a dosage of $240 \mathrm{mcg} / \mathrm{kg}$ body weight. (Sanofi licencing distribution in Italy)

Patients were categorized as proven or predicted PMs, according to the Gruppo Italiano Trapianto di Midollo Osseo (GITMO) criteria. ${ }^{21}$ Patients were considered to be "proven PMs" when the peak concentration of PB CD34+ cells, after adequate mobilization, was fewer than $20 \times 10^{6}$ cells/L or if the concentration of CD34+ cells collected with up to three apheresis procedures was not more than $2.0 \times 10^{6} \mathrm{CD} 34+$ cells $/ \mathrm{kg}$ and considered to be "predicted PMs" if they had failed a previous collection attempt (not otherwise specified), previously received extensive radiotherapy or full courses of therapy affecting stem cell mobilization, and met two of the following criteria: advanced disease (at least two lines of chemotherapy), refractory disease, extensive marrow involvement or cellularity less than $30 \%$ at the time of mobilization, or age at least 65 years. $^{21}$

\section{Data storage}

Data were collected in a centralized secured database and were analyzed at the end of the study. The database consisted of three different parts: 1) demographic characteristics and previous history of mobilization; 2) type of mobilization; and 3) posttransplantation follow-up.

\section{Endpoints and data analysis}

Two endpoints were established to evaluate mobilization success: 1) at least $2 \times 10^{6} \mathrm{CD} 34+$ cells $/ \mathrm{kg}$ body weight collected with up to three leukapheresis procedures and 2) a peak count of at least $20 \times 10^{6} / \mathrm{L} \mathrm{CD} 34+$ cells $\times 10^{6} / \mathrm{L} \mathrm{PB}$ during mobilization. ${ }^{21}$

The fold increase of CD34+ cells $\times 10^{6} / \mathrm{L}$ after the administration of plerixafor was also calculated, to determine the increase of PB CD34+ progenitor cells before and after the administration of plerixafor. The correlation between the platelet (PLT) concentration and the endpoints were investigated using receiver operating characteristic (ROC) curves. A ROC curve permits a comparison of two operating characteristics or variables as the values change to enable thresholds to be established-in this case comparing endpoints with other variables, to better 
differentiate patients likely to reach the endpoints (i.e., achieve successful mobilization) from those not reaching the endpoints. ${ }^{22}$

Patients were stratified according to several variables: age; sex; "predicted" versus "proven" PM category; chemotherapy versus steady-state mobilization strategy; diagnosis (NHL, HL, MM); the number of chemotherapy regimens preceding plerixafor administration; use of fludarabine, radiation therapy, melphalan, carmustine, lenalidomide, and radioimmune conjugates; and laboratory variables (hemoglobin, PLT count, white blood cells [WBCs], and neutrophils). Each variable was tested using univariate statistical analysis, to establish whether it could discriminate patients reaching the endpoint from those not reaching the endpoint, thus becoming a possible significant predictor of mobilization after plerixafor therapy. The chi-square test or Fisher's exact test was used for categorical variables, according to the number of samples. For continuous normally distributed variables, the $t$ test was applied, whereas the Wilcoxon test was used for nonnormally distributed variables. The two endpoints were analyzed separately and $p$ values of less than 0.05 were considered significant.

To identify the factors able to predict the outcome of plerixafor treatment, a multivariate logistic regression model was calculated using only the variables that were significant in the univariate analysis as covariates. Covariates were considered to significantly affect the prediction if the $\mathrm{p}$ value was less than 0.05 .

Finally, Kaplan-Meier curves were drawn to evaluate the relationship between the number of plerixafor doses and the endpoints. All the analyses were conducted on the population as a whole and on the subpopulations of predicted PMs and proven PMs.

\section{RESULTS}

\section{Baseline characteristics}

The baseline characteristics of the study patients are shown in Table 1. In total, 218 patients were enrolled (114 males; 52\%). The mean age was $55.6 \pm 11.6$ years (range, 17-76 years). Approximately half of the patients ( $\mathrm{n}=108$; $49.5 \%)$ were affected by NHL; 23 patients (10.6\%) had HL and $84(38.5 \%)$ had MM. Three patients were diagnosed with other hematologic diseases (one subject with plasma cell leukemia, one with Richter syndrome, and one with immune thrombocytopenia purpura) and were not included in the subsequent analysis; therefore, 215 patients with NHL $(\mathrm{n}=108)$, HL $(\mathrm{n}=23)$, or MM $(\mathrm{n}=84)$ requiring mobilization of PBSCs were included in the study. Concerning the mobilization status (predicted PM vs. proven $\mathrm{PM}$ ) before plerixafor administration, data were available for 207 patients: among these, 64 (30.9\%) were predicted PMs and 143 (69.1\%) were proven PMs.

\begin{tabular}{|c|c|c|}
\hline \multicolumn{3}{|c|}{$\begin{array}{l}\text { TABLE 1. Baseline demographics and clinical } \\
\text { characteristics in the total population }\end{array}$} \\
\hline Variable & Subgroup & Total \\
\hline Age (years) & $55.6 \pm 11.6(17-76)$ & \\
\hline Sex & & 215 \\
\hline Male & $114(52.2)$ & \\
\hline Female & $104(47.8)$ & \\
\hline \multicolumn{3}{|c|}{ Diagnosis and mobilization strategy } \\
\hline MM & & $84(38.5) \dagger$ \\
\hline Chemotherapy & $46(58.0)$ & \\
\hline Steady state & $33(42.0)$ & \\
\hline $\mathrm{NHL}$ & & $108(49.5)$ \\
\hline Chemotherapy & $53(56.0)$ & \\
\hline Steady state & $41(44.0)$ & \\
\hline $\mathrm{HL}$ & & $23(10.6)$ \\
\hline Chemotherapy & $17(77.0)$ & \\
\hline Steady state & $5(23.0)$ & \\
\hline Other & $3(1.4)$ & \\
\hline Mobilization categorył & & 207 \\
\hline Predicted PM & $64(30.9)$ & \\
\hline Proven PM & $143(69.1)$ & \\
\hline Mobilization strategy & & 212 \\
\hline Chemotherapy & $86(40.6)$ & \\
\hline Steady state & $126(59.4)$ & \\
\hline \multicolumn{3}{|c|}{$\begin{array}{l}\text { * Data are reported as mean } \pm \text { SD (range) or number }(\%) \text {. } \\
\dagger \text { Note that not all details were available for all patients. Per- } \\
\text { centages are given accordingly. } \\
\ddagger \text { According to GITMO criteria. }{ }^{21}\end{array}$} \\
\hline
\end{tabular}

In total, 86 patients received G-CSF after chemotherapy, according to different schedules (for six patients data unknown): 40 patients $(50 \%)$ received high-dose cyclophosphamide $\left(\geq 3 \mathrm{~g} / \mathrm{m}^{2}\right) ; 14$ patients $(17.5 \%)$ were treated with DHAP (dexamethasone, ARA-C, cisplatin) regimen; five patients $(6.3 \%)$ with etoposide $\left(1 \mathrm{~g} / \mathrm{m}^{2}\right.$, Vepesid, Bristol-Myers Squibb, Rome, Italy); seven patients (8.8\%) with cytarabine $\left(3 \mathrm{~g} / \mathrm{m}^{2}\right.$, Aracytin, Janssen-Cilag, Berchem, Belgium); three patients (3.8\%) with a mitoxantrone, cytarabine, and dexamethasone (MAD) regimen and 10 patients (12.5\%) with other regimens. In the 126 remaining patients, PBSC mobilization was based on G-CSF $(10 \mu \mathrm{g} / \mathrm{kg})$ in combination with plerixafor $(240 \mu \mathrm{g} / \mathrm{kg}$ body weight $)$ without chemotherapy (steady state).

\section{Efficacy of plerixafor}

Overall, more than the $60 \%$ of patients enrolled in the study reached the endpoints, measured either as the number of CD34+ cells/ $\mathrm{kg}$ collected (145 patients, $68.1 \%$ ) or as the peak value of circulating CD34+ cells $\times 10^{6} / \mathrm{L}(118$ patients, $60.8 \%$; Table 2). In total, 61 patients (35.5\%) reached the endpoint of at least $2 \times 10^{6} \mathrm{CD} 34+/ \mathrm{kg}$ with one apheresis procedure, and $80(46.5 \%)$ with two apheresis procedures, so that more than $80 \%$ of patients $(n=141)$ reached the target with no more than two apheresis procedures.

The high response rate was observed after both steady state (G-CSF) and chemomobilization (Table 2). However, in NHL patients, chemomobilization was 


\begin{tabular}{|c|c|c|c|c|c|c|c|c|}
\hline \multirow[b]{3}{*}{ Patient characteristics } & \multicolumn{5}{|c|}{ CD34+ cells $/ \mathrm{kg}$} & \multicolumn{3}{|c|}{ CD34+ cells $\times 10^{6} / \mathrm{L}$} \\
\hline & \multicolumn{3}{|c|}{$\begin{array}{c}\text { Nonmobilizer } \\
\left(<2 \times 10^{6} \mathrm{cells} / \mathrm{kg}\right)\end{array}$} & \multicolumn{2}{|c|}{$\begin{array}{c}\text { Mobilizer } \\
\left(>2 \times 10^{6} \mathrm{cells} / \mathrm{kg}\right)\end{array}$} & \multicolumn{2}{|c|}{$\begin{array}{c}\text { Nonmobilizer } \\
\left(<20 \times 10^{6} \text { cells/L) }\right.\end{array}$} & \multirow{2}{*}{$\begin{array}{c}\text { Mobilizer } \\
\frac{\left(>20 \times 10^{6} \text { cells } / \mathrm{L}\right)}{<20}\end{array}$} \\
\hline & $<0.5$ & $0.5-1$ & $1-2$ & $2-5$ & $>5$ & $<10$ & $10-20$ & \\
\hline Total population & $46(21.6)$ & $6(2.8)$ & $16(7.5)$ & $84(39.4)$ & $61(28.7)$ & $38(19.6)$ & $38(19.6)$ & $118(60.8)$ \\
\hline \multicolumn{9}{|l|}{ Diagnosis } \\
\hline NHL & $29(27.1)$ & $5(4.7)$ & $11(10.3)$ & $62(57.9)$ & & $28(29.8)$ & $19(20.2)$ & $47(50)$ \\
\hline $\mathrm{HL}$ & $6(26.1)$ & $0(0.0)$ & $1(4.3)$ & $16(69.6)$ & & $4(20.0)$ & $5(25.0)$ & $11(55)$ \\
\hline MM & $10(12.4)$ & $1(1.3)$ & $3(3.8)$ & 19 (23.8) & $47(58.7) \dagger$ & $6(7.8)$ & $13(16.9)$ & $58(75.3)$ \\
\hline \multicolumn{9}{|l|}{ Mobilization category $\ddagger$} \\
\hline Predicted PM & $14(22.0)$ & & & $49(78.0)$ & & $18(34)$ & & $35(66)$ \\
\hline Proven PM & $49(35.0)$ & & & $90(65.0)$ & & $58(42)$ & & $80(58)$ \\
\hline \multicolumn{9}{|l|}{ Mobilization strategy } \\
\hline Chemotherapy & $37(32.0)$ & & & $80(68.0)$ & & $49(44)$ & & $62(56)$ \\
\hline Steady state & $21(26.0)$ & & & $59(74.0)$ & & $23(31)$ & & $52(69)$ \\
\hline \multicolumn{9}{|c|}{ Diagnosis and mobilization strategy } \\
\hline \multicolumn{9}{|c|}{$\mathrm{NHL}$} \\
\hline Chemotherapy & $12(29.0)$ & & & $29(71.0)$ & & $14(36)$ & & $25(64)$ \\
\hline Steady state & $24(45.0)$ & & & $29(55.0)$ & & $30(61)$ & & $19(39)$ \\
\hline \multicolumn{9}{|l|}{$\mathrm{HL}$} \\
\hline Chemotherapy & $2(40.0)$ & & & $3(60.0)$ & & $1(33)$ & & $2(67)$ \\
\hline Steady state & $4(24.0)$ & & & $13(76.0)$ & & $7(44)$ & & $9(56)$ \\
\hline \multicolumn{9}{|l|}{ MM } \\
\hline Chemotherapy & $7(21.0)$ & & & $26(79.0)$ & & $8(25)$ & & $24(75)$ \\
\hline Steady state & 7 (16.0) & & & $38(84.0)$ & & $11(25)$ & & $33(75)$ \\
\hline $\begin{array}{l}\text { * Data are reported as } \\
\dagger \text { At least } 4 \times 10^{6} \mathrm{CD} 3 \\
\ddagger \text { According to GITMO }\end{array}$ & ff for MM & atients) & & & & & & \\
\hline
\end{tabular}

associated with a higher proportion of patients reaching the end points compared with patients mobilized with plerixafor plus G-CSF alone (64\% vs. $39 \%$ for the proportion of patients with peak CD34+ during mobilization of at least $20 \times 10^{6} / \mathrm{L}$ CD34+ cells $\times 10^{6} / \mathrm{L}$ and $71 \%$ vs. $55 \%$ for the number of CD34+ cells $/ \mathrm{kg}$ collected $\geq 2 \times 10^{6} \mathrm{CD} 34+$ cells $/ \mathrm{kg}$ with up to three leukapheresis procedures), although these differences did not reach significance.

Patients with MM showed the highest response rate with $82.5 \%$ of patients with more than $2 \times 10^{6} \mathrm{CD} 34+$ cells $/ \mathrm{kg}$ collected in up to three apheresis procedures and $75.3 \%$ patients with a peak value of more than $20 \times 10^{6}$ CD34+ cells/L, compared to other patients $(p=0.0016$, Table 3).

Overall, the data showed a fivefold increase of PB CD34+ cells $\times 10^{6} / \mathrm{L}$ after plerixafor administration (Fig. 1). The fold increase was higher for NHL patients (6.8 times) and lower for HL patients (3.3 times) and there was no difference in fold increase between predicted PM and proven PM (Fig. 1).

At the time of data analysis, of 126 (57.0\%) patients receiving ASCT, 118 cases (95\%) engrafted. Six patients did not engraft due to early death after auto-ASCT. A transplant-related mortality of $5 \%$ (six patients) was observed. Analysis of the cumulative percentage of patients reaching the endpoints (Fig. 2) showed that almost $90 \%$ reached the defined study endpoints after three doses of plerixafor.

\section{Predictive factors for mobilization success}

Statistical analysis showed that baseline PLT concentration was the most powerful predicting factor for successful stem cell mobilization (Table 3). The ROC curve estimation provided significant discrimination thresholds of $140 \times 10^{9} / \mathrm{L}$ to reach more than $2 \times 10^{6} \mathrm{CD} 34+$ cells $/ \mathrm{kg}$ and $143 \times 10^{9} / \mathrm{L}$ to reach more than $20 \times 10^{6} \mathrm{CD} 34+$ cells/L. Lack of radiotherapy was also a significant predictor of successful stem cell mobilization (Table 3 ). The only other factor predicting poor mobilization in the overall population was the previous use of fludarabine. In particular, patients previously treated with fludarabine were significantly less capable of reaching the endpoints $(20 \%$ vs. $60 \% ; \mathrm{p}=0.0009$ in the univariate analysis). In the multivariate analysis, these three variables, but not type of disease, still kept a significant predictive capacity for successful mobilization.

Overall similar observations came from the analysis of predicted PM (Table 4) and proven PM (Table 5): PLT concentration was the only factor with a discriminant capability. As in the total population, the estimation of the ROC curve for PLT concentration provided a threshold for 


\begin{tabular}{|c|c|c|c|c|c|c|}
\hline Endpoint & Factor & Categories & Nonmobilizer & Mobilizer & $\begin{array}{c}p \text { value } \\
\text { univariate }\end{array}$ & $\begin{array}{c}\mathrm{p} \text { value } \\
\text { multivariate }\end{array}$ \\
\hline \multirow[t]{15}{*}{ CD34+ cells/kg } & Diagnosis & $\mathrm{NHL}$ & $45(42.1)$ & $62(57.9)$ & 0.0016 & NS \\
\hline & & $\mathrm{HL}$ & $7(30.4)$ & $16(69.6)$ & & \\
\hline & & MM & $14(17.5)$ & $66(82.5)$ & & \\
\hline & Mobilization status & Predicted & $14(22.0)$ & $49(78.0)$ & NS & Not considered \\
\hline & & Proven & $49(35.0)$ & $90(65.0)$ & & \\
\hline & Mobilization strategy & Chemotherapy & $37(32.0)$ & $80(68.0)$ & NS & Not considered \\
\hline & & Steady state & $21(26.0)$ & $59(74.0)$ & & \\
\hline & PLTs $\left(\times 10^{9} / \mathrm{L}\right)$ & Number & 59 & 140 & $<0.0001$ & $<0.0001$ \\
\hline & & Mean \pm SD & $116.48 \pm 69.83$ & $176.52 \pm 89.33$ & & \\
\hline & & $\leq 100$ & $22(49)$ & $23(51)$ & 0.0013 & $<0.0001$ \\
\hline & & $>100$ & $37(24)$ & $117(76)$ & & \\
\hline & & $\leq 140^{*}$ & $38(44)$ & $49(56)$ & 0.0001 & $<0.0001$ \\
\hline & & $>140^{\star}$ & $21(19)$ & $91(81)$ & & \\
\hline & Radiotherapy & No & $46(27)$ & $122(73)$ & 0.028 & 0.044 \\
\hline & & Yes & $15(47)$ & 17 (53) & & \\
\hline \multirow[t]{15}{*}{ CD34+ cells $\times 10^{6} / \mathrm{L}$} & Diagnosis & $\mathrm{NHL}$ & $47(50)$ & $47(50)$ & NS & NS \\
\hline & & $\mathrm{HL}$ & $9(45)$ & $11(55)$ & & \\
\hline & & MM & $19(25)$ & $58(75)$ & & \\
\hline & Mobilization category $\dagger$ & Predicted & $18(34)$ & $35(66)$ & NS & Not considered \\
\hline & & Proven & $58(42)$ & $80(58)$ & & \\
\hline & Mobilization strategy & Chemotherapy & $49(44)$ & $62(56)$ & NS & Not considered \\
\hline & & Steady state & $23(31)$ & $52(69)$ & & \\
\hline & PLTs $\left(\times 10^{9} / \mathrm{L}\right)$ & Number & 71 & 117 & $<0.0001$ & $<0.0001$ \\
\hline & & Mean \pm SD & $122.56 \pm 67.54$ & $178.32 \pm 89.50$ & & \\
\hline & & $\leq 100$ & $26(60)$ & $17(40)$ & 0.0005 & 0.0004 \\
\hline & & $>100$ & $45(31)$ & $100(69)$ & & \\
\hline & & $\leq 143^{\star}$ & $46(54)$ & $39(46)$ & $<0.0001$ & 0.0002 \\
\hline & & $>143^{*}$ & $25(24)$ & $78(76)$ & & \\
\hline & Fludarabine & No & $63(36)$ & $111(64)$ & 0.0009 & 0.0175 \\
\hline & & Yes & $12(80)$ & $3(20)$ & & \\
\hline
\end{tabular}

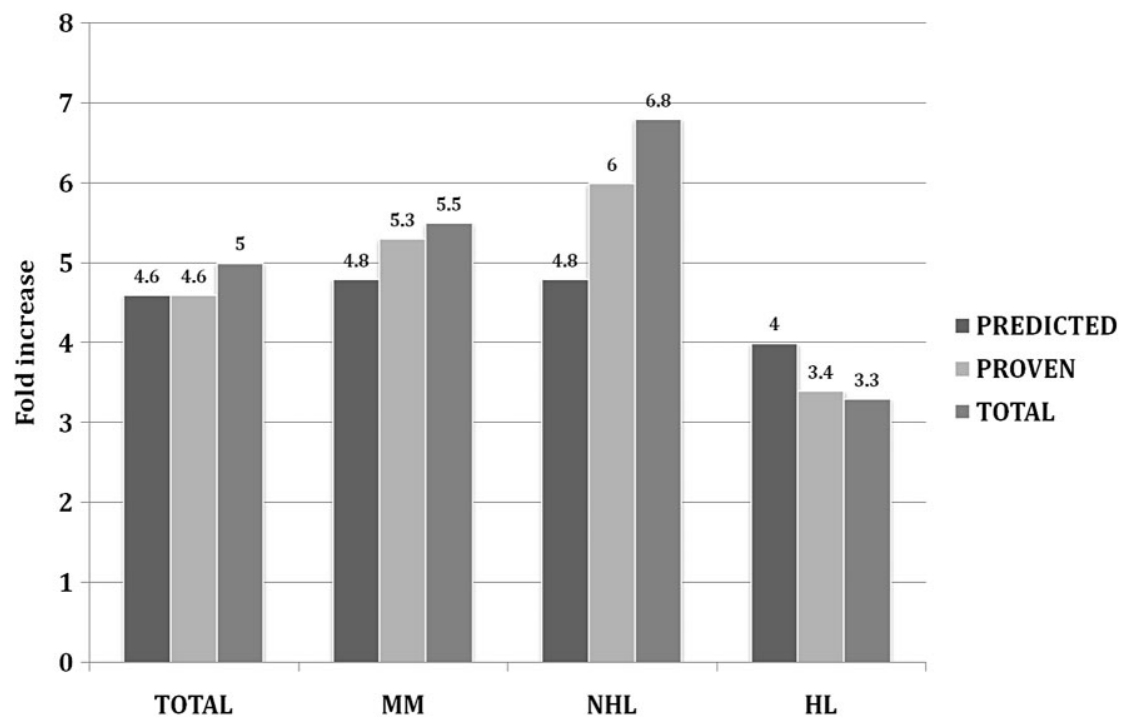

Fig. 1. Fold increase in CD34+ cells $\times 10^{6} / \mathrm{L}$ after plerixafor treatment in predicted and proven PMs and in the total population.

discriminating patients likely to reach the endpoints from those not likely to reach the endpoints. Notably, when examining the univariate analysis of the predicted PMs, patients who did not receive fludarabine had a higher probability of reaching the endpoints ( $80 \%$ vs. $20 \%$ for $>2 \times 10^{6} \mathrm{CD} 34+$ cells $/ \mathrm{kg}$ and $75 \%$ vs. $0 \%$ for $>20 \times 10^{6} \mathrm{CD} 34+$ cells $/ \mathrm{L} ; \mathrm{p}<0.05$ [Table 4]), whereas this factor was not significant in the proven population in the univariate analysis (Table 5).

For CD34+ cells $\times 10^{6} / \mathrm{L}$, the predictive multivariate model was calculated only for the proven PM population, because the low number of cases in the predicted poor population did not allow a reliable estimation.

When we analyzed the number of CD34+ cells collected/kg in different patient subpopulations, the only factor with a predictive capability, both in the univariate and in the multivariate model, was the PLT concentration. This finding was present in all patient categories.

The statistical analysis also showed a correlation between the peak of CD34 cells $\times 10^{6} / \mathrm{L}$ and the harvest of CD34 cells $/ \mathrm{kg}$ in patients treated with plerixafor (Spearman coefficient, 0.78704; $\mathrm{p}<0.0001$ ). ROC curve analysis 


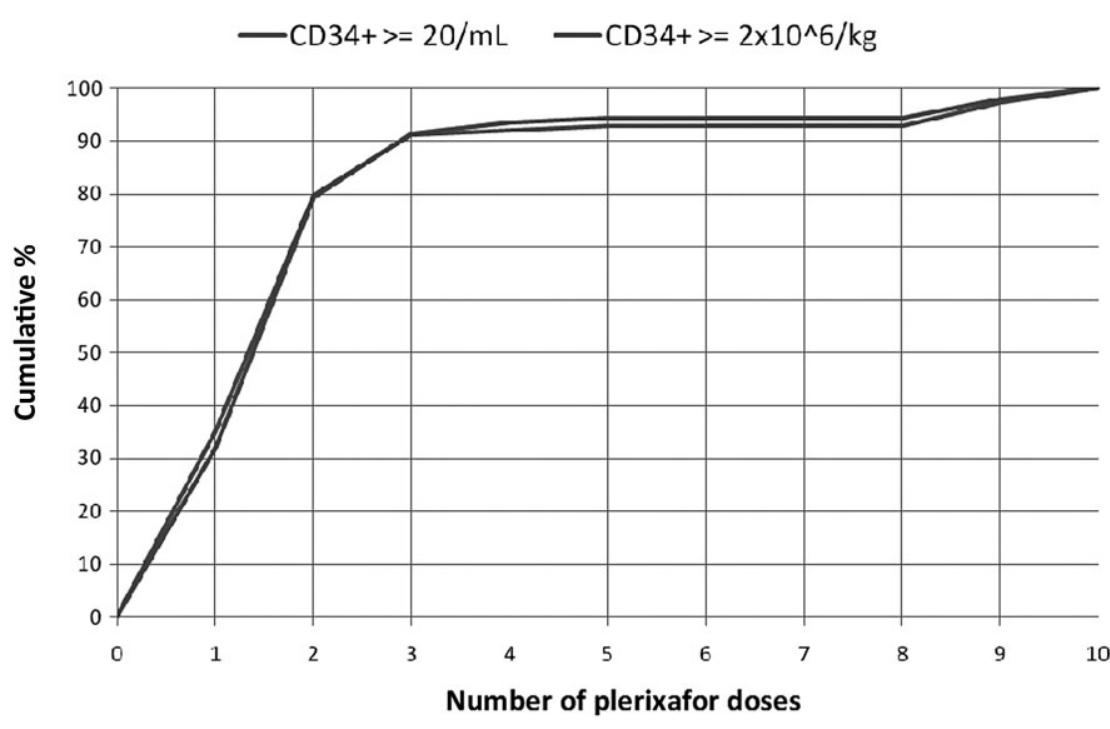

Fig. 2. Cumulative percentage of patients reaching the efficacy endpoints in relation to the number of plerixafor doses. (-) At least $20 \times 10^{6} \mathrm{CD34}+\mathrm{L}$; (-) at least $2 \times 10^{6} \mathrm{CD34+} / \mathrm{kg}$.

further permitted the estimation of a significant discrimination threshold of $4 \mu \mathrm{L}$ of CD34+ cells for a successful mobilization with plerixafor.

\section{DISCUSSION}

The results presented here confirmed, on a large database including more than 200 patients from several Italian centers, the efficacy of plerixafor in inducing stem cell mobilization and, for the first time, identified factors predictive of successful mobilization after the administration of this novel agent. Our results are in agreement with those obtained in randomized, Phase III and compassionate-use program trials, ${ }^{8-10,13-20,23}$ in which the administration of plerixafor produced a successful mobilization with a median increase of approximately fivefold in patients with MM and NHL. We found no significant difference between the response of patients who were predicted PMs or proven PMs. Moreover, we did not observe any difference between steady state and chemotherapy mobilization, thus suggesting that plerixafor can be incorporated successfully into both regimens.

Preliminary studies in patients previously failing the first mobilization attempt reported a successful rate ranging from $37 \%$ to $90 \% .^{15,17,18}$ Our results on a larger Italian database were similar, with more than $60 \%$ of the total population reaching the endpoints. Our results also confirm that rates of successful mobilization tend to be lower in patients with NHL than in patients with MM or HL. ${ }^{9}$ In addition, in our study, approximately $90 \%$ of patients reaching the endpoint needed no more than three doses of plerixafor and two apheresis procedures.
Moreover, a high correlation between increased likelihood of mobilization success and increased number of CD34+ cells present in the mobilized blood was documented; a cutoff point of $4 \times 10^{6} \mathrm{CD} 34+/ \mathrm{L}$ cells best predicted success in a plerixafor-containing mobilization regimen. Based on this, it can be postulated that the presence of at least $4 \times 10^{6} \mathrm{CD} 34+/ \mathrm{L}$ cells in the mobilized blood, prior plerixafor administration, identified patients who most benefited from plerixafor usage in all patient categories.

In our population the analysis of factors potentially able to influence the treatment outcome was different from those reported in previous studies. ${ }^{8,18}$ We failed to demonstrate that patients who underwent previous ASCT had a lower median number of CD34+ cells collected than those who did not undergo ASCT. Moreover, previous chemotherapy was not a significant factor discriminating patients reaching the endpoint from those not reaching the endpoint, neither in the total population nor in the two subgroups (predicted vs. proven), except for the use of fludarabine. In fact, in our population only $20 \%$ of the patients who were treated with fludarabine achieved the endpoint of at least $20 \times 10^{6} \mathrm{CD} 34+/ \mathrm{L}$, compared to the $64 \%$ of those who did not receive fludarabine. This difference was greater than reported in the literature $(60 \%$ vs. $76 \%){ }^{10}$ The subanalysis by proven or predicted PMs showed that this effect was only seen in patients who were predicted PMs (using both endpoints).

Our analysis also allowed the definition of a baseline PLT concentration threshold that may be used as a predictive factor for successful mobilization with plerixafor. In fact, baseline thrombocytopenia was a significant predictor of reduced mobilization success, although plerixafor treatment was able to overcome this effect partially. Overall, a PLT count of fewer than $150 \times 10^{9} / \mathrm{L}$ was significantly associated with a lower probability of successful mobilization regardless of the endpoint considered or in all subgroups of patients.

In conclusion, our study shows that the administration of plerixafor produced a successful mobilization in lymphoma and myeloma patients, both in predicted and in proven PMs, independent of the type of mobilization (steady state or chemotherapy). We also identified some factors, including baseline PLT concentration, previous fludarabine treatment, and previous radiotherapy, which, in a multivariate model, may be able to predict the successful mobilization with plerixafor. 


\begin{tabular}{|c|c|c|c|c|c|c|}
\hline \multirow[b]{2}{*}{ Endpoint } & \multirow[b]{2}{*}{ Factor } & \multirow[b]{2}{*}{ Categories } & \multirow[b]{2}{*}{ Nonmobilizer } & \multirow[b]{2}{*}{ Mobilizer } & \multicolumn{2}{|c|}{$p$ value } \\
\hline & & & & & Univariate & Multivariate \\
\hline \multirow[t]{15}{*}{ CD34+ cells/kg } & Diagnosis & $\mathrm{NHL}$ & $10(33)$ & $20(67)$ & NS & NS \\
\hline & & $\mathrm{HL}$ & $1(13)$ & $7(87)$ & & \\
\hline & & MM & $3(12)$ & $22(88)$ & & \\
\hline & Mobilization strategy & Chemotherapy & $5(14)$ & $30(86)$ & NS & Not considered \\
\hline & & Steady state & $9(32)$ & $19(68)$ & & \\
\hline & PLTs $\left(\times 10^{9} / \mathrm{L}\right)$ & $\mathrm{N}$ & 14 & 47 & 0.0052 & 0.043 \\
\hline & & Mean \pm SD & $101.71 \pm 77.98$ & $193.38 \pm 109.88$ & & \\
\hline & & $\leq 100$ & $7(50)$ & $7(50)$ & 0.011 & NS \\
\hline & & $>100$ & $7(15)$ & $40(85)$ & & \\
\hline & & $\leq 103^{*}$ & $9(53)$ & $8(47)$ & 0.0005 & 0.027 \\
\hline & & $>103^{\star}$ & $5(11)$ & 39 (89) & & \\
\hline & Fludarabine & No & $10(18)$ & $47(82)$ & 0.0014 & NS \\
\hline & & Yes & $4(80)$ & $1(20)$ & & \\
\hline & WBCs & $\mathrm{N}$ & 14 & 47 & 0.0199 & NS \\
\hline & & Median & 6.14 & 15.36 & & \\
\hline \multirow[t]{16}{*}{ CD34+ cells $\times 10^{6} / \mathrm{L}$} & Diagnosis & $\mathrm{NHL}$ & $11(44)$ & $14(56)$ & NS & Not estimated \\
\hline & & $\mathrm{HL}$ & $2(40)$ & $3(60)$ & & \\
\hline & & MM & $5(22)$ & $18(78)$ & & \\
\hline & Mobilization strategy & Chemotherapy & $10(33)$ & $20(67)$ & NS & \\
\hline & & Steady state & $8(35)$ & $15(65)$ & & \\
\hline & PLTs $\left(\times 10^{9} / \mathrm{L}\right)$ & Number & 17 & 34 & 0.046 & \\
\hline & & $\begin{array}{l}\text { Mean } \pm \text { SD } \\
<100\end{array}$ & $\begin{array}{c}126.18 \pm 82.17 \\
6(50)\end{array}$ & $189.76 \pm 113.53$ & NS & \\
\hline & & $>100$ & $11(28)$ & $28(72)$ & INo & \\
\hline & & $\leq 143^{*}$ & $11(55)$ & $9(45)$ & 0.0084 & \\
\hline & & $>143^{\star}$ & $6(19)$ & $25(81)$ & & \\
\hline & Fludarabine & No & $13(28)$ & $34(72)$ & 0.0033 & \\
\hline & & Yes & $5(100)$ & $0(0)$ & & \\
\hline & WBCs & Number & 17 & 34 & 0.0021 & \\
\hline & & Median & 4.70 & 22.68 & & \\
\hline & Neutrophil count $\left(\times 10^{9} / L\right)$ & Number & 17 & 29 & 0.012 & \\
\hline & & Median & 3.24 & 8.5 & & \\
\hline
\end{tabular}

TABLE 5. Significant predictive factors in the proven PM population $(n=144)$

\begin{tabular}{|c|c|c|c|c|c|c|}
\hline Endpoint & Factor & Categories & Nonmobilizer & Mobilizer & $\mathrm{p}$ value univariate & $p$ value multivariate \\
\hline \multirow[t]{13}{*}{ CD34+ cells $/ \mathrm{kg}$} & \multirow[t]{3}{*}{ Diagnosis } & $\mathrm{NHL}$ & $30(43)$ & $39(57)$ & \multirow[t]{3}{*}{0.034} & \multirow[t]{3}{*}{ NS } \\
\hline & & $\mathrm{HL}$ & $6(40)$ & $9(60)$ & & \\
\hline & & $\mathrm{MM}$ & $11(21)$ & $41(79)$ & & \\
\hline & \multirow[t]{2}{*}{ Mobilization type } & Chemotherapy & $32(40)$ & $50(61)$ & \multirow[t]{2}{*}{ NS } & \multirow[t]{2}{*}{ Not considered } \\
\hline & & Steady state & $12(25)$ & $37(75)$ & & \\
\hline & \multirow[t]{6}{*}{ PLTs $\left(\times 10^{9} / \mathrm{L}\right)$} & Number & 45 & 90 & \multirow[t]{2}{*}{0.001} & \multirow[t]{2}{*}{0.0017} \\
\hline & & Mean \pm SD & $121.07 \pm 67.37$ & $163.61 \pm 70.05$ & & \\
\hline & & $\leq 100$ & $15(48)$ & $16(52)$ & \multirow[t]{2}{*}{0.043} & \multirow[t]{2}{*}{0.027} \\
\hline & & $>100$ & $30(29)$ & $74(71)$ & & \\
\hline & & $\leq 129^{*}$ & $24(46)$ & $28(54)$ & \multirow[t]{2}{*}{0.012} & \multirow[t]{2}{*}{0.0069} \\
\hline & & $>129^{\star}$ & $21(25)$ & $62(75)$ & & \\
\hline & \multirow[t]{2}{*}{ Sex } & Male & $21(27)$ & $56(73)$ & \multirow[t]{2}{*}{0.028} & \multirow[t]{2}{*}{ NS } \\
\hline & & Female & $28(45)$ & $34(55)$ & & \\
\hline \multirow[t]{11}{*}{ CD34+ cells $\times 10^{6} / \mathrm{L}$} & \multirow[t]{3}{*}{ Diagnosis } & $\mathrm{NHL}$ & $36(53)$ & $32(47)$ & \multirow[t]{3}{*}{ NS } & \multirow[t]{3}{*}{ NS } \\
\hline & & $\mathrm{HL}$ & $7(47)$ & $8(53)$ & & \\
\hline & & MM & $14(27)$ & $38(73)$ & & \\
\hline & \multirow[t]{2}{*}{ Mobilization type } & Chemotherapy & $39(48)$ & $42(52)$ & \multirow[t]{2}{*}{ NS } & \multirow[t]{2}{*}{0.0166} \\
\hline & & Steady state & $15(31)$ & $34(69)$ & & \\
\hline & \multirow[t]{6}{*}{ PLTs $\left(\times 10^{9} / \mathrm{L}\right)$} & $\mathrm{N}$ & 54 & 80 & \multirow[t]{2}{*}{0.0001} & \multirow[t]{2}{*}{$<0.0001$} \\
\hline & & Mean \pm SD & $121.42 \pm 63.09$ & $168.91 \pm 71.60$ & & \\
\hline & & $\leq 100$ & $20(65)$ & $11(35)$ & \multirow[t]{2}{*}{0.0017} & \multirow[t]{2}{*}{0.0003} \\
\hline & & $>100$ & 34 (33) & $69(67)$ & & \\
\hline & & $\leq 142^{*}$ & $35(54)$ & $30(46)$ & \multirow{2}{*}{0.0019} & \multirow{2}{*}{0.0013} \\
\hline & & $>142^{\star}$ & $19(27)$ & $50(73)$ & & \\
\hline
\end{tabular}

* Cutoff obtained by ROC curve analysis. 


\section{ACKNOWLEDGMENTS}

This study was approved by GITMO (Italian Society for Stem Cell Transplantation). Editorial assistance and statistical analysis of data were provided by Luca Giacomelli, PhD, Mary Hines, and Chiara Favero, on behalf of inScience Communications, Springer Healthcare.

\section{CONFLICT OF INTEREST}

$\mathrm{FL}, \mathrm{AB}, \mathrm{RML}$, and AR were members of an advisory board for Genzyme s.r.l. The rest of the authors declare that they have no conflict of interest.

\section{REFERENCES}

1. Rosenbeck LL, Srivastava S, Kiel PJ. Peripheral blood stem cell mobilization tactics. Ann Pharmacother 2010;44:10716.

2. Jantunen E, Fruehauf S. Importance of blood graft characteristics in auto-SCT: implications for optimizing mobilization regimens. Bone Marrow Transplant 2011;46:627-35.

3. Vose JM, Ho AD, Coiffier B, Corradini P, Khouri I, Sureda A, Van Besien K, Dipersio J. Advances in mobilization for the optimization of autologous stem cell transplantation. Leuk Lymphoma 2009;50:1412-21.

4. Bensinger W, DiPersio JF, McCarty JM. Improving stem cell mobilization strategies: future directions. Bone Marrow Transplant 2009;43:181-95.

5. Pusic I, Jiang SY, Landua S, Uy GL, Rettig MP, Cashen AF, Westervelt P, Vij R, Abboud CN, Stockerl-Goldstein KE, Sempek DS, Smith AL, DiPersio JF. Impact of mobilization and remobilization strategies on achieving sufficient stem cell yields for autologous transplantation. Biol Blood Marrow Transplant 2008;14:1045-56.

6. Giralt S, Stadtmauer EA, Harousseau JL, Palumbo A, Bensinger W, Comenzo RL, Kumar S, Munshi NC, Dispenzieri A, Kyle R, Merlini G, San Miguel J, Ludwig H, Hajek R, Jagannath S, Blade J, Lonial S, Dimopoulos MA, Einsele H, Barlogie B, Anderson KC, Gertz M, Attal M, Tosi P, Durie BG et al. International myeloma working group (IMWG) consensus statement and guidelines regarding the current status of stem cell collection and high-dose therapy for multiple myeloma and the role of plerixafor (AMD 3100). Leukemia 2009;23:1904-12.

7. Han X, Ma L, Zhao L, He X, Liu P, Zhou S, Yang J, Qin Y, Yang S, Yao J, Shi Y. Predictive factors for inadequate stem cell mobilization in Chinese patients with NHL and HL: 14-year experience of a single-center study. J Clin Apher 2012;27:64-74.

8. Duarte RF, Shaw BE, Marin P, Kottaridis P, Ortiz M, Morante C, Delgado J, Gayoso J, Goterriz R, MartinezChamorro C, Mateos-Mazon JJ, Ramirez C, de la Rubia J, Achtereekte H, Gandhi PJ, Douglas KW, Russell NH. Plerixafor plus granulocyte CSF can mobilize hematopoietic stem cells from multiple myeloma and lymphoma patients failing previous mobilization attempts: EU compassionate use data. Bone Marrow Transplant 2011;46:52-8.

9. Hubel K, Fresen MM, Apperley JF, Basak GW, Douglas KW, Gabriel IH, Geraldes C, Jaksic O, Koristek Z, Kroger N, Lanza F, Lemoli RM, Mikala G, Selleslag D, Worel N, Mohty M, Duarte RF. European data on stem cell mobilization with plerixafor in non-Hodgkin's lymphoma, Hodgkin's lymphoma and multiple myeloma patients. A subgroup analysis of the European Consortium of stem cell mobilization. Bone Marrow Transplant 2012;47:1046-50.

10. Malard F, Kroger N, Gabriel IH, Hubel K, Apperley JF, Basak GW, Douglas KW, Geraldes C, Jaksic O, Koristek Z, Lanza F, Lemoli R, Mikala G, Selleslag D, Worel N, Mohty M, Duarte RF. Plerixafor for autologous peripheral blood stem cell mobilization in patients previously treated with fludarabine or lenalidomide. Biol Blood Marrow Transplant 2012;18:314-7.

11. Duong HK, Bolwell BJ, Rybicki L, Koo A, Hsi ED, Figueroa P, Dean R, Pohlman B, Kalaycio M, Andresen S, Sobecks R, Copelan E. Predicting hematopoietic stem cell mobilization failure in patients with multiple myeloma: a simple method using day 1 CD34+ cell yield. J Clin Apher 2011;26: 111-5.

12. Keating GM. Plerixafor: a review of its use in stem-cell mobilization in patients with lymphoma or multiple myeloma. Drugs 2011;71:1623-47.

13. DiPersio JF, Micallef IN, Stiff PJ, Bolwell BJ, Maziarz RT, Jacobsen E, Nademanee A, McCarty J, Bridger G, Calandra G. Phase III prospective randomized double-blind placebo-controlled trial of plerixafor plus granulocyte colony-stimulating factor compared with placebo plus granulocyte colony-stimulating factor for autologous stemcell mobilization and transplantation for patients with non-Hodgkin's lymphoma. J Clin Oncol 2009;27:4767-73.

14. DiPersio JF, Stadtmauer EA, Nademanee A, Micallef IN, Stiff PJ, Kaufman JL, Maziarz RT, Hosing C, Fruehauf S, Horwitz M, Cooper D, Bridger G, Calandra G. Plerixafor and G-CSF versus placebo and G-CSF to mobilize hematopoietic stem cells for autologous stem cell transplantation in patients with multiple myeloma. Blood 2009;113:5720-6.

15. Arcaini L, Laszlo D, Rizzi S, Balzarotti M, Antoniazzi F, Zilioli VR, Guggiari E, Farina L, Todisco E, Bonfichi M, Alamos SM, Rossi G, Martinelli G, Morra E. Plerixafor and G-CSF for PBSC mobilization in patients with lymphoma who failed previous attempts with G-CSF and chemotherapy: a REL (Rete Ematologica Lombarda) experience. Leuk Res 2011;35:712-4.

16. Calandra G, McCarty J, McGuirk J, Tricot G, Crocker SA, Badel K, Grove B, Dye A, Bridger G. AMD3100 plus G-CSF can successfully mobilize CD34+ cells from non-Hodgkin's lymphoma, Hodgkin's disease and multiple myeloma patients previously failing mobilization with chemotherapy and/or cytokine treatment: compassionate use data. Bone Marrow Transplant 2008;41:331-8. 
17. Worel N, Rosskopf K, Neumeister P, Kasparu H, Nachbaur D, Russ G, Namberger K, Witt V, Schloegl E, Zojer N, Linkesch W, Kalhs P, Greinix HT. Plerixafor and granulocytecolony-stimulating factor (G-CSF) in patients with lymphoma and multiple myeloma previously failing mobilization with G-CSF with or without chemotherapy for autologous hematopoietic stem cell mobilization: the Austrian experience on a named patient program. Transfusion 2011;51:968-75.

18. Basak GW, Jaksic O, Koristek Z, Mikala G, Basic-Kinda S, Mayer J, Masszi T, Giebel S, Labar B, Wiktor-Jedrzejczak W. Haematopoietic stem cell mobilization with plerixafor and G-CSF in patients with multiple myeloma transplanted with autologous stem cells. Eur J Haematol 2011;86:488-95.

19. D’Addio A, Curti A, Worel N, Douglas K, Motta MR, Rizzi S, Dan E, Taioli S, Giudice V, Agis H, Kopetzky G, Soutar R, Casadei B, Baccarani M, Lemoli RM. The addition of plerixafor is safe and allows adequate PBSC collection in multiple myeloma and lymphoma patients poor mobilizers after chemotherapy and G-CSF. Bone Marrow Transplant 2011;46:356-63.

20. Attolico I, Pavone V, Ostuni A, Rossini B, Musso M, Crescimanno A, Martino M, Iacopino P, Milone G, Tedeschi P, Coluzzi S, Nuccorini R, Pascale S, Di Nardo E, Olivieri A. Plerixafor added to chemotherapy plus G-CSF is safe and allows adequate PBSC collection in predicted poor mobilizer patients with multiple myeloma or lymphoma. Biol Blood Marrow Transplant 2012;18:241-9.

21. Olivieri A, Marchetti M, Lemoli R, Tarella C, Iacone A, Lanza F, Rambaldi A, Bosi A. Proposed definition of "poor mobilizer" in lymphoma and multiple myeloma: an analytic hierarchy process by ad hoc working group Gruppo Italiano Trapianto di Midollo Osseo. Bone Marrow Transplant 2012;47:342-51.

22. Hanley JA, McNeil BJ. The meaning and use of the area under a receiver operating characteristic (ROC) curve. Radiology 1982;143:29-36.

23. Micallef IN, Stiff PJ, DiPersio JF, Maziarz RT, McCarty JM, Bridger G, Calandra G. Successful stem cell remobilization using plerixafor (mozobil) plus granulocyte colonystimulating factor in patients with non-Hodgkin lymphoma: results from the plerixafor NHL phase 3 study rescue protocol. Biol Blood Marrow Transplant 2009;15: 1578-86.

\section{SUPPORTING INFORMATION}

Additional Supporting Information may be found in the online version of this article at the publisher's web-site:

Appendix S1. Institutions contributing to the study. 